Sri Lanka J. Aquat. Sci. 11 (2006): 21-26

\title{
Price efficiency in tuna fish marketing in Sri Lanka - An application of cointegration approach
}

\author{
Y.Y.K. DE SILVA, P.S.K. RAJAPAKSHE AND K.H.M.L. \\ AMARALAL ${ }^{3}$
}

${ }^{1,3}$ National Aquatic Resource Research and Development Agency, Crow Island, Colombo 15, Sri Lanka

${ }^{2}$ Faculty of Social Science \& Humanities, Rajarata University of Sri Lanka, Mihintale, Sri Lanka

*Corresponding author (E-mail: yasantha@doc.gov.lk)

\begin{abstract}
The intention of this study was to investigate whether the tuna fish markets in Sri Lanka were integrated to bring efficiency in the marketing system. The empirical analysis of this paper was based on time series monthly data of tuna fish prices in selected wholesale and retail fish markets in Colombo, Kalutara and Kandy during the time period of 2000 to 2004. The bivariate price series correlation and Engle-Granger test were used to analyze the market cointegration for Sri Lanka tuna fish markets. The Augmented Dickey Fuller (ADF) test was applied to test the stationary of the price series. To check the short run dynamics of fish markets the Error correction model was applied. The bivariate correlation coefficients for six selected market pairs ranged between 0.403 and 0.85 . The highest correlation coefficient value (r) was observed from the market pair of Colombo and Kalutara retail markets. The lowest ' $r$ ' value was observed from the market pair of Colombo and Kandy wholesale markets. All the selected six tuna fish markets price series were found to be non-stationary when ADF test was carried out. The results revealed that the price series for tuna fish prices in the selected six markets were stationary after first difference. The cointegration test and error correction model revealed that all the selected tuna fish markets in Sri Lanka were integrated and showed short run stability. In this case the results revealed that the tuna fish markets in Sri Lanka were somewhat competitive. But, further, government intervention needs to improve competitiveness of tuna fish marketing and to enhance the market efficiency.
\end{abstract}




\section{Introduction}

In a competitive market with free flow of information, the price difference between any two regions will be equal to or less than transport costs between the two markets. Under perfect competition, a market would be distinguished by features such as large number of buyers and sellers, perfect knowledge about market conditions, homogeneity of product, and free mobility of buyers, sellers and product. Thus a single price will prevail in all markets. Price differentials for a particular commodity arising from place, time and form difference would correspond closely to the costs incurred in providing the respective transportation, storage and processing facilities. The market will perform efficiently and there will be no scope for traders to make excessive profits. The pricing system would facilitate exchange and fully reflect the underlying supply and demand conditions (Ahamad and Habibullah 1994).

There are basically two approaches to investigate the issue of competitiveness in a market. The first is to establish whether the structure of the market tends to conform to the general criteria for a competitive market. The second is to determine whether price movements reflect a state of competitiveness in the market. To check the price movements in different markets, cointegration tests were widely used. The market integration refers to a situation in which prices of a commodity in spatially separated markets move together and price signals and information are transmitted smoothly across the market (Ghosh 2000). Therefore, in this study an attempt has been made to find out whether tuna fish markets in Sri Lanka are integrated to bring about efficiency in the marketing system.

\section{Materials and Methods}

This study uses monthly time series wholesale and retail tuna fish prices from different marketing centers in Sri Lanka for the period from January 2000 to December 2004. The marketing centers selected were Colombo, Kandy and Kalutara. Sixty data points were collected from each center. Bivariate price correlation as well as methodology developed by the Engle and Granger (1987) has been used to show whether tuna fish market are cointegrated or not. The Pearson correlation coefficient for the prices in each pair of selected markets can be estimated by the following formula.

$\mathrm{r}=\frac{\sum\left(\mathrm{P}_{1 \mathrm{n}}-\mathrm{P}_{1}\right)\left(\mathrm{P}_{2 \mathrm{n}}-\mathrm{P}_{2}\right)}{\sqrt{ } \sum\left(\mathrm{P}_{1 \mathrm{n}}-\mathrm{P}_{1}\right)\left(\mathrm{P}_{2 \mathrm{n}}-\mathrm{P}_{2}\right)^{2}}$

Where;

r- Pearson Correlation Coefficient

$\mathrm{P}_{1 \mathrm{n}}$-Price of the commodity in the first market at $\mathrm{n}^{\text {th }}$ point of time 
$\mathrm{P}_{2 \mathrm{n}}$ - Price of the commodity in the Second market at th point of time

$\mathrm{P}_{1}$-Mean of prices in the first market

$\mathrm{P}_{2}$-Mean of prices in the second market

Estimates of correlation coefficient were tested using t test. To examine the price relation between the two markets the following regression model has been used.

$\mathrm{P}_{\mathrm{at}}=\alpha_{0}+\alpha_{1} \mathrm{P}_{\mathrm{bt}}+\mathrm{U}_{\mathrm{t}}$

Where $\mathrm{P}_{\mathrm{a}}$ and $\mathrm{P}_{\mathrm{b}}$ are price series of a specific commodity in two markets a and $b$ and $U$ is the residual terms assume to be distributed randomly. Parameter $\alpha_{0}$ be represents transportation cost, processing cost, etc. The test of market integration is straight forward if $\mathrm{P}_{\mathrm{a}}$ and $\mathrm{P}_{\mathrm{b}}$ are stationary variables.To test the univariate price series for stationary the Argumented Dickey Fuller (ADF) test has been applied, which test the null hypothesis of non stationary against an alternative of stationary. The standard equation of the $\mathrm{ADF}$ test is given below.

$\Delta \mathrm{P}_{\mathrm{t}}=\alpha+\beta \mathrm{P}_{\mathrm{t}-1}+\epsilon_{\mathrm{a}=1} \mathrm{C}_{\mathrm{i}} \Delta \mathrm{P}_{\mathrm{t}-1}+\mathrm{U}_{\mathrm{t}}$

The test statistics is simply the t- statistics, however under the null hypothesis it is not distributed as student $t$, but the ratio can be compared with critical values tabulated in Dickey and Fuller (1979). In estimating equation (2) the null hypothesis is $H_{0} P_{t}$ is 1 (1), which is rejected if $\beta-1$ is found to be negative and statistically significant.

To adjust short run behavior with long run behavior Error Correction Model (ECM) equation was applied.

$\Delta \mathrm{P}_{\mathrm{at}}=\mathrm{a}_{0}+\mathrm{a}_{1} \Delta \mathrm{P}_{\mathrm{bt}}+\delta \mathrm{U}_{\mathrm{t}-1}+\mathrm{e}_{\mathrm{t}}-{ }_{-}-{ }_{-}$

\section{Results and Discussion}

Table 1 represents the bivariate correlation coefficients among the price series of the selected market pairs in Sri Lanka. In the correlation matrix it is clear that wholesale and retail prices are moderately correlated. The highest correlation coefficient value has been observed for the market pairs containing retail prices of Kalutara and Colombo and lowest for the market pairs containing wholesale price of Colombo and Kandy. It should be noted that the correlation coefficient of market price between Kalutara and Colombo is very high compared to Kandy because the distance between these markets are very short. It is evident from Table 1 that all the correlation coefficient of wholesale prices is above 0.403 . The high value of correlation coefficient implies that the markets are highly interdependent in price 
formation. The correlation coefficient of retail prices lies between 0.603 and 0.850. This result also implies that the retail markets are highly interdependent in price formation. The result indicates that correlation coefficients of retail markets are comparatively higher than wholesale markets.

Table 1: Correlation matrix of wholesale and retail prices of different fish markets in Sri Lanka

\section{$\begin{array}{llllll}\text { Kan-W } & \text { Kal-W } & \text { Col-W } & \text { Kan-R } & \text { Kal-R } & \text { Col-R }\end{array}$}

$\begin{array}{lllllll}\text { Kan-W } & 1.000 & & & & & \\ \text { Kal-W } & 0.591 * & 1.000 & & & & \\ \text { Col-W } & 0.403^{*} & 0.433^{*} & 1.000 & & & \\ \text { Kan-R } & 0.704^{*} & 0.648 * & 0.567^{*} & 1.000 & & \\ \text { Kal-R } & 0.791^{*} & 0.412 * & 0.656^{*} & 0.668^{*} & 1.000 & \\ \text { Col-R } & 0.756^{*} & 0.405^{*} & 0.694^{*} & 0.603^{*} & 0.850^{*} & 1.000\end{array}$

*Correlation is significant at the 0.01 level (2 tailed)

The result of the ADF test applied to marine fish price series in the selected markets of Sri Lanka are presented in Table 2. Two stages of the ADF test have been carried out initially test has been performed on the price series in levels, which implied testing a null hypothesis that the series are integrated of the order 1 or higher against an alternative that the series are $\mathrm{i}(0)$. The result of this stage is shown in the Table 2 . The null hypothesis could not be rejected even at $10 \%$ level for any of the price series.

Table 2: ADF Tests result for tuna fish price series of selected markets in Sri Lanka

\begin{tabular}{ccc}
\hline Markets & Level $\{1(1)\}$ ADF Test & $\begin{array}{c}\text { First difference }\{1(2)\} \\
\text { ADF Test }\end{array}$ \\
\hline Kan-W & -3.015 & -5.115 \\
Kal-W & -2.678 & -4.900 \\
Col-W & -3.105 & -6.394 \\
Kan-R & -1.789 & $-3.213^{* *}$ \\
Kal-R & -3.012 & -5.922 \\
Col-R & -2.987 & -5.192 \\
\hline
\end{tabular}

**Significance at $10 \%$ level

Following that, tests are also performed on the first difference of the price series which implied testing a null hypothesis that the price series are 
integrated of the order two or higher, against and alternative that the series are $i(1)$. The result of this stage is shown in Table 3.

Table 3: Summary matrix of cointegration tests for wholesale and retail prices of Tuna fish among selected market pairs

\begin{tabular}{|lcccccc|}
\hline & Kan-W & Kal-W & Col-W & Kan-R & Kal-R & Col-R \\
\hline Kan-W & - & -6.21 & -6.73 & -6.43 & -5.12 & -4.75 \\
Kal-W & & - & -4.95 & -4.83 & -5.31 & -5.05 \\
Col-W & & & - & -5.34 & -4.59 & -6.10 \\
Kan-R & & & & - & -5.78 & -4.35 \\
Kal-R & & & & & - & -5.28 \\
Col-R & & & & & & \\
\hline
\end{tabular}

Critical value at 1 percent level -3.96

The tuna fish markets of Sri Lanka are integrated and market mechanism plays an important role through influencing the price change in one market to another market. Table 4 presents the results of error correction model for wholesale and retail markets. It is revealed from the table that the coefficient of error term are negative and statistically significant for the wholesale and retail fish markets in Sri Lanka, implying that there exists short run dynamics with the long run equilibrium.

Table 4. Results of Error Correction Model of whole sale and retail fish markets in Sri Lanka

\begin{tabular}{|c|c|}
\hline Fish Market & Result of Error Correction Model \\
\hline $\begin{array}{l}\text { For Wholesale Fish } \\
\text { Markets }\end{array}$ & $\begin{aligned} & \Delta \text { Kan-W }=-0.469+0.535 \Delta \text { Col-W }-0.559 \mathrm{u}_{\mathrm{t}-1} \\
&(1.301) \quad(0.086) \\
& \Delta \text { Col-W }=-0.131+0.697 \Delta \text { Kal-W }-0.168 \mathrm{u}_{\mathrm{t}-1} \\
&(1.302) \quad(0.091) \\
& \Delta \text { Kal-W }= 0.205+0.462 \Delta \text { Kan-W }-0.005 \mathrm{u}_{\mathrm{t}-1} \\
& \quad(1.88) \quad(0.148)\end{aligned}$ \\
\hline $\begin{array}{l}\text { For Retail } \\
\text { Markets }\end{array}$ & 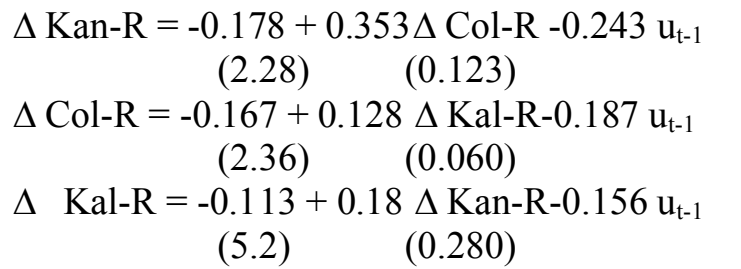 \\
\hline
\end{tabular}




\section{Conclusions}

In this study, we adopted the cointegration method developed by Engle and Granger (1987) to analyze the long run relationship between prices in different fish markets. The bivariate correlation coefficients for selected market pairs ranged between 0.403 and 0.850 . The higher correlation coefficient value has been observed for the Kalutara and Colombo retail markets and the lowest correlation coefficient value has been observed for Colombo and Kandy Wholesale markets. Thus, on the basis of the value of correlation coefficient the wholesale and retail prices of fish in Sri Lanka are seen to be moderately correlated. All the selected marine fish markets, price series are found to be non stationary when ADF test was carried out. The levels thus necessitating further test on the first difference of the price series. The ADF test revealed that the price series for selected tuna fish markets in Sri Lanka are stationary after first difference. Then error correction model was applied to test whether selected tuna fish markets are integrated or not. Result revealed that coefficient of error term are negative and statistically significant for the wholesale and retail fish markets in Sri Lanka, implying that there exists short run dynamics with the long run equilibrium. The high degree of market integration shows that selected fish markets in Sri Lanka are competitive and efficient at the whole sale level.

\section{References}

Ahamed, Z.B. \& M.S. Habibullah 1994.

Price efficiency in pepper markets in Malaysia: A cointegration analysis. Indian Journal of Agricultural Economics 49:205-214.

Dickey, D.A. \& W.A. Fuller 1979.

Distribution of the estimation for autoregressive time series with a unit root test. Journal of American Statistical Association 74:427-443

Engle, R.F.C. \& C.W.J. Granger 1987.

Cointegration and error correction, representation, estimating and testing.Econometrica 55:251-276.

Ghosh, M. 2000.

Cointegration tests and spatial integration of rice markets in India. Indian Journal of Agricultural Economics 55:616-626. 